37) Kloc L., Fiala J., Cadek J., A New Procedure to Evaluate Creep Data Obtained by the Helicoid Spring Specimen Technique under Conditions of Non-viscous Creep Behaviour, Mater. Sci. Eng., Vol. 130, No. 1, (1990), 61.

38）田中良平，吉原美知子，鈴木徽也，NiTi形状記 憶合金の熱サイクル試験，熱処理, Vol. 30, No. 5, (1990), 253.

39）藤木栄，形状記憶合金に関する公開特許とコイ ルば效の熱サイクル特性，材料試験技術，Vol. 35, No. 4. (1990), 263.

40）户伏寿昭，田中樹久昭, 形状記憶合金の機械的 性貿 1 応力ーひずみ一温度関係とその繰返し特 性, 機械の研究, Vol. 43, No. 2, (1991), 247.

41）戸伏寿昭，田中樹久昭，形状記憶合金の機械的 性質 2 応力ーひずみ一温度関係とその繰返し特 性，機械の研究，Vol. 43, No. 3, (1991), 363.

42）戸伏寿昭, 大橋義夫, 堀達哉, 山本英雄, TiNi 形状記憶合金コイルばねの繰返し変形特性(トレー ニングおよび形状記憶熱処理温度の影響), 日本機 械学会論文集A, Vol. 57, No. 533, (1991), 121.

43) Suzuki Y., Tamura H., Fatigue Properties of Shape Memory Alloys, Eng. Shape Mem. Alloy, (1990), 256. (Shape Memory Alloy Technology Conference : East Lansing, Mich.)

44）都築秀和, 堀川宏, $\mathrm{Ni}-\mathrm{Ti}-\mathrm{Cu}$ 形状記憶合金コイ ルばねの熱サイクル特性, 古河電工時報, No. 86, (1990), 54

45）川窪隆昌, 山田文之, 新しい炭素質バネの試作 と特性, 応用物理, Vol. 59, No. 11, (1990), 1521.

46) 松本岩男, 林博, 谷野克己, 中川章, 土肥義治, 樹脂・ファイバー複合材に関する研究, 富山県工 業技術センタ一研究報告, No. 4, (1990), 105.

47）下原伊智朗, 大橋俊彦, 好満芳邦, 西本義雄, 竹内正一, 木原隆司, 杉原芳明, 水崎秦正, 新素 材の加工・利用技術ハイブリッド化による複合素 材の高機能化, 広島県立西部工業技術センター研 究報告, No. 33，(1990)，67.

48) Rao N., Plastics in Primary Structural Automotive Applications, Role Plast. New Am. Econ. Acene, (1987), 222 (BBC Conference on Plastics : Stamford Conn.)

$\left(\begin{array}{ll}\text { 俊野英男 } & \text { (株) 東 郷 製 作 所 } \\ \text { 坂本正雄 } & \text { 金属材料技術研究所 }\end{array}\right)$

\section{4. 光の他,}

(規 格)

ばね関遇の JIS 規格が以下のように利定または改五: された。

B 4111-91 超硬線引ダイス

Cemented carbide dies for drawing wires and rods 一改正 1991年9月1日

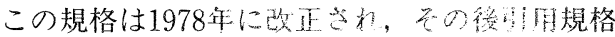
が改正されたのを機会に見淔しが行われた。JIS Z8301の改正により引用規格及び対颂国際規格を 備考として追加し, 表面粗さを $\mathrm{R}_{\max }$ 表示加ら $\mathrm{R}_{\mathrm{a}}$ の表示としている。また，測定器の表現方法を 变更し，引用規格の改正により，製品の㭔び方 を改正している。

B 7725-91 ビッカース硬さ試験機

Vickers hardness testing machines

一一改正 1991年 3 月 1 日 改正前の規格では9.807Nの試験荷重が含まれて いたが，改正によりこれが除外されている。除 外理由として, (1) $9.807 \mathrm{~N}$ の試験荷重は, JIS B7734に以前から含まれている,(2) JIS B7734で は, 9.807Nの試験荷重が必要である, (3) ISOの ビッカース硬さ関係の試験機の検査, 試験方法 の規格において，同一試験荷重を複数の規格で 扱うことがない，が挙げられる．ISO146は，こ の規格よりも試験荷重が広いが，我が国では Hv100の試験機がないため，この規格の上限は Hv50としている.Hv 1 以下はJIS B7734が適 用される。

\section{B7734-91 微小硬さ試験機}

Micro hardness testing machines for Vickers and Knoop hardness

一改正 1991年 3 月 1 日

実際に製作されている試験機に合わせて荷重の 下限を $98.07 \mathrm{mN} \sim 9.807 \mathrm{mN}$ としている.この規 格は,ビッカース硬さについては, ISO146と ISO/ DIS146/2に対応し,ヌープ硬さについてはISO/ DIS4546に対応している.

B 7451-91 真円度測定機

Roundness measuring machines

一一制定 1991年 8 月 1 日 工作機械で加工されるシリンダ, 軸, 軸受など の部品において, 真円度はそれぞれの部品の機 能に影響を与える重要な品質管理項目である。 真円度を測定する方法としては直径法, 三点法, 半径法があり，これらは測定の用途と目的や要 求する精度により使い分けられている。また， 
真円度を測定する機器は，半径法を用いたもの が早くから工業化されており, 真円度測定器と しての規格化が待たれていた。

\section{G 3521-91 硬鋼線}

Hard drawn steel wires

—改正 1991年 9 月 1 日 鋼線規格は,臨JES 第583号として1944年 4 月 28 日に初めて制定され，戦後日本金属規格に切り 換えられたが，工業標準化法施行に伴い1953年 12月19日に硬引鋼線の名称でJIS となった。そ の後1957年ピアノ線規格が，ばる用を主体に大 幅に改正され，これに伴い1958年に名称も硬銅 線として大幅な改正が行われた。今回の改正で は, JIS G3521と G3522を並行して見直すと同時 に ISO8458-1,2 (Steel wire for mechanical springs)にも整合するよう改正されている。従来 硬鋼線とピアノ線は個別に見直しているため, 主として同じばね用鋼線にもかかわらず，横並 びでみた場合整合性に欠ける面もあったが，今 回の改正では整合性を図り品質差を明確にしょ うとする努力がみられる。今问の見直しに当り， 例えば $\mathrm{B}$ 種， C種を分離し，ばね用硬鋼線にす るなどの意見もあつたが, 鋼線関係の分割, 統 合は関連業界で充分審議する必要があるため今 回この案件は見送られた。

\section{G3522-91 ピアノ線}

Piano wires

一改正 1991年 9 月 1 日 今回の改正ではJIS G3522(ピアノ線)と JIS G3521 (硬鋼線)を並行して見直すと同時に, ISO8458-1,2にも整合するよj改正されている. 従来ピアノ線と硬鋼線は個別に見直しているた め，主として同じばね用鋼線にもかかわらず， 横並びで見た場合，整合性に欠ける面もあった が，今回の改正では整合性を図り品質差を明確 にしようと努力されている。また，今回の見直 しに当たって，例えば弁ばね用ピアノ線をこの 規格から分離し，オイルテンパー線関係の規格 と同じように，用途別にした方が品質格差を明 確にできるのではないかなどの規格体系に関す る意見もあったが，今回は見送られた。

\section{K5551-91 エポキシ樹脂塗料}

Epoxy resin paint

一制定 1991年 8 月 1 日

エポキシ樹脂塗料は, 橋りょう(梁), 鋼構造物, プラント，建築物などの分野の防食塗装系の下
塗り，上塗り塗料として，長年にわたって使用 されている。橋り上う用, 建築用としては, 自 治休, 公団などで制定した規格があるが, JIS と してはまだ制定されていないので，この規格が 制定されることになった。

K5552-91 ジンクリッチプライマー

Zinc rich primer 一制定 1991年 8 月 1 日 ジンクリッチプライマーは, 船舶，橋りょう， 鋼構造物, プラント, 建築物などの鋼材の素地 調整後の防せい(錆)に用いる塗料で，エッチン グプライマーに比べて，暴露耐用期間が長いた め, 塗装工事が長期間にわたるような大型鋼構 造物に多く使用されている。橋り上う用として は自治体，公団などで制定した規格があるが, JIS はまだ制定されておらず,この規格が制定さ れることになった。

\section{K5553-91 厚膜形ジンクリッチペイント}

High build type zinc rich paint

一一制定 1991年 8 月 1 日 厚膜形ジンクリッチペイントは, 船舶, 橋りょ う, 鋼構造物, プラント, 建築物などにおける 重防食塗装の分野で，プラスト面に直接塗装す る第 1 層目の塗料として長年にわたって用いら れてきている(塗装系によってはジンクリッチプ ライマーの上に塗り重㸚る場合もある)。なお， 同じジンクリッチ系塗料である JIS K5552が約 $20 \mu \mathrm{m} /$ 回の膜厚で鋼材の一次プライマーとして 使用されるのに対し，この規格の厚膜形ジンク リッチペイントは,一般には $50 \sim 100 \mu \mathrm{m} /$ 回の膜 厚で使用されるという違いがある。橋りょう用 としては自治体，公団などで制定した規格があ るが, JIS はまだ制定されておらずこの規格が 制定されることになった。

\section{Z 2252-91 高温ビッカース硬さ試験方法}

Test methods for Vickers hardness at elevated temperatures

一一制定 1991年 8 月 1 日 この規格では，高温硬さとして実績のあるビッ カース硬さだけを対象とし, 他の硬さは測定例 が極めて少ないので含められていない。ビッカ 一ス硬さ用の高温試験機の場合、圧子をヌープ 圧子に交換すればヌープ硬さを測定することは 可能であるが，金属材料に対する高温又ープ硬 さ測定例がほとんどなかったので今回の規格に 入れられていない。常温のビッカース硬さ試験 
方法の規格及び試験機の規格では荷重範囲を別 に規定しているが, ビッカース硬さは原理的に は荷重には依存しないので,この規格では, 通 常微小ビッカース硬さと呼ばれる範囲にも適用 し, 特に荷重範囲は制限していない。適用温度 の上限は $800^{\circ} \mathrm{C}$ とている.これ以上の温度でも 圧子の損傷等を覚悟すればある程度まで可能と 思われるが規格として保証しきれない面がある ので本規格では $800^{\circ} \mathrm{C}$ までとしている.

\section{Z 2300-91 非破壊試験用語}

Glossary of terms used in nondestructive testing 一一制定 1991年 3 月 1 日 非破壊試験及び評価に関する工業技術用語を主 とし, 学術的用語も配虑されている。用語の定 義は厳密さよりも工業的に理解しやすいものと することを心掛けてある。

\section{Z 2314-91 渦流探傷器の性能測定方法}

Test methods for performance characteristics of eddy current testing instruments

一一制定 1991年 9 月 1 日 この規格では対比試験片を使用しないため擬似 欠陥信号を電気的に発生する方法が採用されて いる。この方法により対比試験片を機械的に動 かす必要がなく安定, 容易な測定が可能である. また， 入力と出力間の性能の測定であるため, 容易, かつ, 確実に必要な性能が測定可能であ る。この規格の適用に当たっては, 目的に応し て適切な管理限界を設定することが重要であり, 材料規格などにおいてこの管理限界を定める必 要がある.

\section{Z 2315-91＼cjkstart渦流探傷装置の総合性能の測定方法}

Test methods for performance characteristics of eddy current flaw detecting system

一一制定 1991年 3 月 1 日 この規格は, 探傷器, 記録装置, 送り装置, 磁 気飽和装置など装置全体が示す性能に関するも のである。探傷器の個別の性能に関しては別の 規格で定められる。

\section{Z 2319-91 漏えい(洩)磁束探傷試験方法}

Methods for magnetic leakage flux testing 一一制定·1991年 3 月 1 日 我が国における漏えい磁束探傷試験は, 主とし て棒鋼及び鋼管に適用されていることから, 棒 鋼及び鋼管を対象とした規定である、試験体の 大きさについては, 現在市販されている試験装 置が対応できる最大範囲としている。この規格 による試験方法は, 角ビレットなどにも適用可 能である。漏えい磁束探傷試験方法ではきず深 さと漏えい磁束との間によい相関があり，きず 深さの推定が可能である。これは, 磁粉探傷試 験方法と比べたとき, 漏えい磁束探傷試験方法 の大きな利点の一つである.

$$
\left(\begin{array}{ll}
\text { 宮川 信勇 } & \text { 京浜発條(侏) } \\
\text { 小曾根敏夫 } & \text { 中央発條(侏) } \\
\text { 增田順一 } & \text { N T T }
\end{array}\right)
$$

